\title{
A Comparative Analysis of Migration Policies: (Best) Practices from Europe
}

\author{
Tünde PATAY \\ Doctoral School of Regional and Economic Sciences, \\ Széchenyi István University, Győr, Hungary \\ E-mail: tuende.patay@wien.gv.at
}

\begin{abstract}
Migration is one of the main factors that shape and accelerate the development of nations or urban areas, although the dynamics and combined effects of migratory movements, national policies, and the roles of local authorities present a mixed picture in Europe. Some countries have restrictive immigration and integration policies, other nations provide easier access to their political and welfare systems, while the question of local responsibility has also acquired particular importance in recent years. The aim of this study is to explain the linkages between migration policy and development, exploring the variety of European integration policies and their effects on the national socio-economic structures. The integration policy has progressively been becoming ever more important over the last decades. The analysis presents how integration tools interact with national or regional development, emphasizing the role of different migration strategies.
\end{abstract}

Keywords: Europe, integration policy, migration, regional development

JEL Classifications: J15, K37

\section{Introduction}

The European states face different migratory challenges. National and local governments have been learning for decades how to manage migration and control its effects. The elements of European migration policy aim to harmonize the legislative and administrative instruments (European Commission, 2003). Europe intends to maximize the positive effects of migratory flows while finding solutions for social, economic, environmental, and political challenges (European Commission, 2000). The European Union emphasizes the opportunities and calls our attention to the potential that immigration has for the development of the European states (European Commission, 2015). 
Migration policies contain in summary all the legal norms which are in relation to human migratory movements or the changes in residential status being able to affect migratory trends and their effects and not only the labor market consequences (Oltmer, 2017). Summarizing the studies on migration policies, Feleky and Vincze define three basic attitudes to migration in the European political platform: selective excluding attitude, policy of total assimilation, and pluralist attitude (2010) - I only agree in part with this statement since the aspects of the results can vary. Lack of integration could have negative effects besides those on the main areas of competitiveness, the democratic representation, and accountability (Jones-Correa, 1998). The consequences of success or lack of integration scatter further just like the spread or backwash effect of Myrdal (1960). Thus, integration strategies should cover all the key areas of growth and well-being: labor market, education, welfare system, housing environment, or civic and political life - systematically, such as how urban development strategies have to be worked out (Palmai, Patay, 2014). Goodhart (2004) argues that it is hard to maintain equilibrium between sustaining a modern welfare state and acceptable migration policies that ensure easier access to welfare services. Recognition of cultural differences, granting rights to immigrants without a selective procedure (legal requirements) can be advantageous for immigrants but not for the host population, undermining the development of the welfare system - as Barry argues (2001). Other achievements point out that supporting multiculturalism - as a policy approach - means aiming at full protection against discrimination and exclusion that leads to marginalization (Banting, Kymlicka, 2006).

Global competitiveness motivates provinces and cities to work to attract and retain creative and talented human capital (Florida, 2005). European countries with migratory experiences all have programs on the national level to attract the best (Gafner, Yale-Loehr, 2010), but from local aspects the flows of immigrants also mean challenges caused by ethnic, cultural, or social diversity (Rogers, Tillie, 2001). Varun Uberoi and Tariq Modood point out, however, that successful strategies and anti-discrimination practices remain mainly in place and not countrywide (2013). Moreover, the roles of municipalities have gained importance in recent years due to the implementation of decentralized policies (Balázs, 2003), though experience has shown different types of evolution of modernization in the western and eastern countries (Torma, 2003).

From the practical point of view, studies mainly prefer the national context (Descy, 2016), and it is obvious because the range of citizenship and immigration policies is always defined at the national level. Ideas on measuring immigration policies and their effects have already been discussed among the Member States (Kováts, 2014). We can also find databases on indicators relating to migration policies - they cover policy data of selected countries; they are thus useful but not complete (Ellerman, 2013). Studies have, however, been conducted with focus on 
one highlighted area such as labor market, social challenges, or methodological issues (Bjerre et al., 2014). De Haas, Natter, and Vezzoli demonstrate in their study a long-term trend: the evolution of migration policies of 45 countries. They also call attention to the need of a cross-country comparison of policies and their effects since, as they sum up, researchers have mainly explored some selected host countries with focus on specific migrant groups (2016).

Thus, the aim of this study is to offer a new, comprehensive approach, focusing on the main relations within the policy-migration-development triangle. Furthermore, the study comes to the result that different clusters can be identified on the basis of these variables: macro-regions within Europe and subnational regions within a country. The outcomes can serve as a base for further cross-national or cross-regional investigations. The first section of the study introduces the structure of the modern migratory movements towards the European countries; afterwards, the paper discusses the main fundamental areas of migration policies: citizenship, equal rights, and welfare system. The next paragraphs analyse the importance of the integration policy, with particular attention to the labor market, issues of culture, and spatial segregation. The last section, pointing out the relevance of the regional aspects, explains how local governments perceive and manage the effects of migration. This cross-country comparison undertakes in summary to explain the linkages between migration policy and development, exploring along these lines the variety of European policies and their effects on both the national socio-economic structures and the migratory flows.

\section{Material and Methods}

Its migratory features can characterize Europe, and thus we can distinguish four main regions: Northern Europe (such as Sweden or Finland), South-Western Europe (France, the Netherlands, or Italy), the German-speaking regimes, and the territories of the United Kingdom (Dustmann, Frattini, 2012). The postcommunist countries have other types of experiments in migration and integration issues (Fassmann, Münz, 1996). This paper investigates the migration policies of selected countries from these macro-regions. Besides comparing policies and experiences at the national level, the study is based on secondary national and subnational data. It also discusses (on the basis of the author's dissertation) the importance of regional/local experiments regarding migration. The findings are, if needed, complemented with the results of previous studies related to the issues discussed below. This paper analyses the experiences mainly from the 1990s till the early 2000s, and some issues need an interpretation on the basis of current data as well (till 2014). 
As regards the comparison between Western and Eastern Europe (or the post-communist countries), the immigration practice of Hungary will also be presented in this paper as an example for migratory issues in the post-communist countries despite less experience in the integration of immigrants. This analysis does not examine the current issues of asylum since the pressing challenges of this question should be discussed in particular studies.

\section{Results and Discussion}

\section{Immigration to Europe}

Since the 1980s, European states have been facing the challenge of how to include immigrants on different stages. Like Fassmann and Münz also present in their book (1996), the illusion of temporary or circular migration has disappeared, guest workers stayed in their new homeland. New migratory groups have been arriving: new work force, entrepreneurs, family members, students, refugees, and illegal migrants as well. Migrants make significant contributions to development at the national or local level: with their workforce, experiences, and knowledge but with their cultural characteristics or international connections as well. On the other hand, mobility brings negative effects with: expenditure of the welfare system, conflicts in the society, discrepancies regarding the values and goals of the host community, and, of course, deprivation.

Integration is the process by which immigrants become accepted into the society, getting a range of entitlements depending on their legal status. According to the statistics of the Eurostat, 3.4 million people immigrated in 2014 to the EU28 Member States: 1.4 million third-country nationals, 1.2 million people with citizenship of another EU Member State, and 830 thousand returning migrants.

More than $40 \%$ of the population are non-nationals in Luxembourg. The Northwest European states, such as Austria, Germany, Italy, etc., became host countries after World War II (from the 1950s and 1960s), and today approx. 10\% of their populations are non-nationals. In the era of modern migratory movements, since the first, recruited guest workers - and Britain's post-colonial immigrants - arrived, these host countries have gradually been developing their integration policies at the national and regional level. Table 1 also contains the data for Hungary. Hungary can be considered as an example for the post-communist countries related to migratory issues despite its less experience in the integration of newcomers.

Not only its effects but the definitions of social, economic, or political integration of a newcomer vary (Angenedt, 2000; Treibel, 2011). It means we can hardly find 
a consensus, not even on the political platform of one country. We can find in the political issues - but also in the literature - different terms for assimilation, incorporation, integration, and inclusion. Some of them emphasize the responsibility of the receiving community, some the importance of the willingness of the immigrants, and there can be found theories that say that the success depends on the cooperation of all the actors (see also Council of the European Union, 2004).

Table 1: Key data on immigration - 2014

\begin{tabular}{lccc}
\hline & $\begin{array}{c}\text { Non-nationals in } \% \\
\text { of the population }\end{array}$ & $\begin{array}{c}\text { EU citizens } \\
(\mathbf{1 , 0 0 0 )}\end{array}$ & $\begin{array}{c}\text { 3. nationals } \\
(\mathbf{1 , 0 0 0 )}\end{array}$ \\
\hline Luxembourg & 43.2 & 191 & 30 \\
\hline Austria & 12.3 & 352 & 555 \\
\hline Spain & 12.3 & 2,329 & 3,325 \\
\hline Belgium & 10.6 & 749 & 414 \\
\hline Ireland & 9.2 & 292 & 69 \\
\hline Germany & 9.1 & 2,628 & 3,571 \\
\hline Italy & 8.5 & 1.335 & 2,425 \\
\hline UK & 8.2 & 2,061 & 352 \\
\hline Sweden & 6.7 & 270 & 82 \\
\hline Hungary & 2.1 & 127 & \\
\hline
\end{tabular}

Source: Eurostat, own calculation

\section{Residence and citizenship}

Migration policies of the European countries, just like many analysing studies, consider the issue of citizenship as the main goal or the best instrument for the inclusion of immigrants. Just as for citizenship - so writes Brubaker (1995) -, some conceptions highlight the importance of cultural or ethnic connections, whilst it is only the time spent within the country that counts for the other ones. However, Bauböck (1994) points out that certain entitlements are linked to the legal residential status of the migrants; it is obvious that citizenship is the most common entitlement for a migrant to get full membership rights and thus to take part in political life, too. Based on the legal systems of the European countries, important differences can be observed among the countries in their policies and procedures.

The legislative requirements have gradually been harmonized according to the EU policies in the European countries; in some of them, it is still easier to obtain the citizenship. Sweden and the Netherlands have the highest naturalization rates among the western countries and, despite the recent changes in their legal 
rules and the decreasing percentage of the candidates, still higher than those of Germany or Austria. Regarding Hungary, persons acquiring citizenship were almost exclusively from the Hungarian minority in Romania or from returning diasporas.

As for the residence permit, criteria for obtaining, upgrading, or losing it can vary from country to country, though the spirit of the European Union requires a harmonized legal background. Some social and political rights can only be obtained with long-term permits or after obtaining the citizenship itself, while the requirements for getting them often relate to these social or political circumstances. Austria and Germany have strict rules; however, they are strongly highlighting through the media the importance and priority of human rights or protection of family. If we look at the legislative and administrative practice in these countries, immigrants have to face difficulties getting and holding their permits or later upgrading them into a secure one or into citizenship. Granted access to social welfare, marginalized life periods, crime issues, or just administrative problems can undermine these upgrading goals. Political rights can be fully obtained after having acquired citizenship. At the same time, in the Netherlands and in Sweden or in France, the legal rules are not so strict; the probability of losing a residence permit or the citizenship is low. Besides that, non-nationals have more political rights than in Austria or Germany, e.g. regarding local elections or political participation.

\section{Equal Rights and MIPEX Scores}

Ten years ago, the legal solutions for anti-discrimination were most favourable in the United Kingdom and in the Netherlands (Niessen, Chopin, 2002), but, comparing the legal systems of today, the relevant legislation of the other immigration countries has also developed since then. Discrimination relating to religion is an important topic in each European country, as for most western countries there are deficits in both the legislation and the practice regarding discrimination related to religious differences. The realization of equality is particularly ensured by the legal system in the Netherlands and in Sweden.

Beyond analysing the migration policies and legal issues regarding immigration, the scores of the MIPEX (Migrant Integration Policy Index) can also be useful for us since the overall index is built up from 140 main indicators from the area of the following issues: access to nationality, long-term residence, anti-discrimination, family reunion, labor market access, and political participation. The below table (Table 2) presents the MIPEX indices for 2007, 2010, and 2014 for the countries analysed in this study. 
Table 2. Overall scores of the migration and integration policy indices 2007-2010-2014

\begin{tabular}{lccc}
\hline Country & $\mathbf{2 0 0 7}$ & $\mathbf{2 0 1 0}$ & 2014 $^{\mathbf{1}}$ \\
\hline Austria & 39 & 45 & 50 \\
\hline Belgium & 69 & 68 & 67 \\
\hline France & 55 & 53 & 54 \\
\hline Germany & 53 & 60 & 61 \\
\hline Hungary & $49^{2)}$ & 45 & 45 \\
\hline The Netherlands & 68 & 69 & 60 \\
\hline Sweden & 88 & 80 & 78 \\
\hline Switzerland & 50 & 45 & 49 \\
\hline United Kingdom & 63 & 62 & 57 \\
\hline
\end{tabular}

Notes:

1) Health system included

2) Education not yet evaluated

Sweden has the highest score, offering the easiest access to equal rights. The next ones are the Netherlands and the United Kingdom. The German-speaking countries (Germany, Switzerland, and Austria) have lower scores. It illustrates their strict legal practices, reflecting the difficulties in the realization of equal rights. Regarding Austria, it is the labor market mobility that has had the major political priority. It also means a higher degree of inequality between immigrants and non-immigrants and relatively difficult preconditions for the obtaining of equal rights. The United Kingdom has lower scores, and the integration policy is now finding a new role in the regional and local development.

\section{Access to Welfare Services}

An important issue of the national or regional development is the socioeconomic situation of immigrants, which also depends on the migration policy of the host country and, at the same time, on the national or regional welfare characteristics. Comparing the European welfare structures, besides Belgium or the Netherlands, immigrants (just like non-migrants) have basically easy access to the welfare services in northern Europe such as Sweden. The United Kingdom offers the least protection against market forces for immigrants. In Austria, Germany, and even Switzerland welfare benefits are only granted for immigrants if the strict requirements are fulfilled.

Welfare dependence has an important role in migration management, particularly for the accessibility of citizenship. It is difficult to access citizenship in case 
of welfare dependence in the countries with strict rules, e.g. Austria, Germany, or Switzerland, and welfare supports are not so easy to be obtained either. In this manner, these states can protect and maintain their welfare level, although immigrants - particularly those with low income possibilities - can feel its disadvantages. Belgium, France, the Netherlands, Sweden, and even the United Kingdom offer open naturalization systems for immigrants with welfare dependence as well; thus, equal rights can also be accessed for this social group. The socio-economic situation of immigrants has an influence on the national or urban development. The quantity and quality of immigrant groups depend at the same time on the structure of the national or regional welfare characteristics.

According to Todaro's hypothesis (1969), immigrants leave their home on the grounds of their - often sketchy - conception and information regarding the future possibilities. Derived from the theories of Borjas (1989), Myrdal (1960), and Treibel (2011) but also from several empirical studies, groups with less potential on the market (lack of education, experience, possession, or contact) tend to migrate to countries or urban areas that can offer a secure welfare background or an equal income distribution, while migrants with higher education, more experiences or possessions usually choose a destination with stronger market competition despite the social inequality in the host country. Particularly the first generation of some ethnic groups is satisfied with a humble standard of living (even if they tend to save money for own properties or for remittances); they are thus not intensively interested in cultural assimilation, language acquisition, education, or carrier plans. The second generation often follows the attitudes of their parents, and thus the gap can hardly be reduced (Biffl et al., 2010).

The socio-economic gap between immigrants and the host community is therefore actually widening, and countries that try to provide an equal income distribution system have thus difficulties to maintain this level. Contrary to countries with generous welfare systems, in host countries with strict legal and administrative requirements, immigrants are motivated to improve their chances on the market.

\section{Integration Policies and the Labor Market}

Immigrants with high human capital potential can easier be involved in the labor market and avoid unemployment: e.g. with language knowledge, soft skills, contacts, and other issues of social assimilation. In Austria, Germany, and the United Kingdom, unemployment rates for immigrants are also higher than those of the native population but not as much as in the multicultural regimes. By contrast, countries with multicultural policies, such as Belgium, the Netherlands, or Sweden, have more immigrants with difficulties on the labor market (Table 3). 
Table 3. Unemployment rates of selected countries [as the share of unemployed persons (15-64) in the labor force]

\begin{tabular}{lcccrrr}
\hline & \multicolumn{3}{c}{ Native-born } & \multicolumn{3}{c}{ Foreign-born } \\
\hline Austria & $\mathbf{2 0 0 2}$ & $\mathbf{2 0 0 8}$ & $\mathbf{2 0 1 4}$ & $\mathbf{2 0 0 2}$ & $\mathbf{2 0 0 8}$ & $\mathbf{2 0 1 4}$ \\
\hline Belgium & 4.3 & 3.2 & 4.7 & 8.7 & 7.5 & 10.1 \\
\hline France & 5.7 & 5.9 & 6.9 & 16.7 & 14.6 & 17.4 \\
\hline Germany & 8.0 & 7.0 & 9.1 & 14.2 & 12.0 & 16.0 \\
\hline Hungary & 8.0 & 6.6 & 4.5 & 10.5 & 12.3 & 7.9 \\
\hline The Netherlands & 5.6 & 7.9 & 7.8 & 5.1 & 6.1 & 6.0 \\
\hline Sweden & 2.2 & 2.5 & 6.1 & 5.3 & 6.6 & 12.0 \\
\hline Switzerland & 4.3 & 5.3 & 6.2 & 10.2 & 12.2 & 16.4 \\
\hline UK & 4.1 & 2.4 & 3.3 & 3.0 & 6.2 & 7.7 \\
\hline & 4.9 & 5.6 & 6.1 & 7.6 & 6.7 & 7.1 \\
\hline
\end{tabular}

As for the labor market participation of immigrants, analysing the data of both the OECD and the Eurostat, it is almost at the same level in Austria as that of non-immigrants; however, we can observe differences in view of region, age, country of origin, or skills. In Germany, Switzerland, or the United Kingdom, the native-born population has only approx. $10 \%$ higher rates of participation, while Sweden and the Netherlands have the lowest levels of immigrant participation on the labor market. It means that liberal welfare systems (United Kingdom) and regimes with high requirements (Austria, Switzerland) should show prospective labor market integration outcomes and narrower income gaps. In contrary, countries such as Sweden or the Netherlands have difficulties regarding the integration of immigrants in the labor market.

On the basis of labor market data, the participation of immigrants is higher in countries with a strict legal system regarding naturalization or integration pressures (Austria, Germany, Switzerland) than in countries with easier access to naturalization or lighter assimilation pressures (Sweden, the Netherlands, Belgium).

\section{Cultural and Spatial Segregation}

From the perspective of the outcomes of the integration policies, it is important to distinguish the cultural dimension of these since it is permanently at the centre of controversies as for its definition or measurability (see also Bandelow, 2006; Treibel, 2011). Koopmans et al. (2005) compiled an index that reflects cultural rights and obligations (Table 4). 
Table 4. Koopman's index of cultural rights

\begin{tabular}{lc}
\hline Host country & Scale $(-) \mathbf{1}$ to $(+) \mathbf{1}$ \\
\hline Germany & -0.20 \\
\hline France & -0.52 \\
\hline The Netherlands & +0.76 \\
\hline Switzerland & -0.85 \\
\hline United Kingdom & +0.31 \\
\hline
\end{tabular}

Source: Koopman et al., 2005 - own illustration

The overall score involves the following categories: cultural conditions of naturalization, legal freedom for Islamic everyday practices, provisions for the Islam in institutions, political representation, and integration in the labor market. Along these dimensions (provisions or allowances), the European countries can be positively characterized, e.g.: state funding for religious schools and classes, education in own language, consultative bodies, institutions, financially supported associations, broadcasting time obligations, labor market actions, financial help for trainings and higher education, police and military employment, labor market obligations in the private sector, or even allowances regarding slaughtering of animal or call to prayer.

Beyond the priority of the language, the culture, and customs of the host community, the lack of the provisions mentioned above can be described in summary as barriers to cultural freedom and signals for assimilative goals. As Table 4 also shows, at the time of Koopman's study, the Netherlands, followed by the United Kingdom, granted immigrants a wide range of rights and provisions, demanding less conformity in public institutions; however, several programs and actions of these governances were later not continued any more. Comparing the findings of Koopman with the legislative systems and the integration environment that characterize the European states, Sweden and Belgium can be considered to be on the positive side of this scale (high cultural freedom both in private life and in public environment). Austria is conversely in a position of the negative side of this scale due to its legal rules and definite integration goals, although if we look at the current concepts Austria now provides more representation for immigrants in several public and private areas.

The spatial segregation of immigrants - when this happens under the title of urban development - is regularly considered as a provision of multiculturalism and as an acceptance of cultural rights. Public housing programs and related integration actions have been organized to build and maintain housing estates and districts for special immigrant groups on the basis of their ethnic or religious features, thus segregating them from the host community both spatially and 
socially. However, residential segregation is not only determined by financial circumstances or by national and local instruments. Immigrants have their cultural preferences, and it also affects their residential possibilities (self-segregation). On the basis of a cross-regional comparison of integration concepts (as a part of the author's dissertation), but as a result of some empirical studies (see also Gachter, 2005; Musterd, 2005), segregation seems to be assisted by the concepts of local policies (in some regions of the Netherlands, Belgium, the United Kingdom, Germany, and Austria). Particularly Muslim groups are segregated (Turks, North Africans, Iranians, Algerians, etc.), while the social groups these immigrants come from (e.g. employees with high skills) and the districts they live in also play an important role. Housing programs for immigrants can also be an instrument of integration (assimilation) concepts such as the development concept of Vienna (2014) in the spirit of the STEP.

\section{Subnational Concepts and Instruments}

National and local governments have been learning for decades how to manage migration and its consequences. From the practical point of view, however, most experts have privileged the national context in their studies. This may be because the range of citizenship and immigration policies is always defined at the national level. However, at the local level, policies have more direct effects. So they have on the daily life of migrants, strengthening the linkage between migrants and natives (Penninx et al., 2004). Local governments experience the first challenges brought by ethnic, cultural, and social diversity that immigration causes (Rogers, Tillie, 2001). Comparing the migratory politics and strategies in Europe, it is mainly the local policy that can manage and accelerate the intensity of migrants' incorporation into the community. It is also at the local level that migrants usually have greater opportunities to become involved in political and civic life.

Regarding Austria, despite its humble MIPEX-scoring values, which have been stable over the last years, this country has a wide range of solutions as for the integration of immigrants, both at the national and subnational level. After the breakdown of the Austro-Hungarian Monarchy, the history of migration has also developed in the successive states in different ways. By now, Austria has become a nation with a mixed population, which means that approximately $12 \%$ of the inhabitants are foreign residents and $20.4 \%$ have a migratory background according to the Austrian statistics. The Austrian subnational, local authorities have also recognized the importance of immigrant integration. Different integration instruments have been developed - in Graz, even since the appearance of the first guest workers. However, we can talk about a countrywide intensive integration activity from 2000 onwards. 
In Hungary (just like in several post-communist countries), the migration management is still in another phase. On the one hand, Hungary only became involved in international migration in the late 1980s. On the other hand, the tasks and the performance assessment of the municipalities have only gained importance in the recent years, and the efficient decentralization or modernization has still not yet quite worked out.

Although the labor market is basically controlled at the national level, the regional features of immigration also show interactions with these areas of development.

Table 5. National and subnational competencies in Austria in relation with migratory challenges

\begin{tabular}{lll}
\hline & National level & Subnational level \\
\hline Legal rules & - immigration & - education \\
& - employment & - social aid \\
& - welfare services & - spatial planning \\
& - equal rights & - real property \\
& & - acquisition \\
\hline Priorities & - basic skills & - German language \\
& - dialogues & - schools \\
& - neighborhood & - public sector \\
& - health & - women's integration \\
& - sports & - information transfer \\
\hline Communication & - Austrian culture & - diversity \\
\hline
\end{tabular}

Source: Patay, 2016

As already analysed in this study, the labor market participation of immigrants is higher and unemployment rates are lower in countries with a strict legal system regarding welfare provisions, naturalization, and integration pressures (Austria, Germany, Switzerland). Furthermore, regional differences can be observed among inputs and outcomes of integration solutions within a country. In addition, integration program and labor market possibilities strengthen the phenomenon of immigrant concentration, which multiplies the positive steps of development. For that, the labor market participation of immigrants is high despite the relatively low rate of migratory movements. Female immigrants, both newcomers and residents (1. or 2. generation) are intensively involved in integration program. Their labor market participation is higher than in the other regions, and they have also success in running small businesses. A cooperative attitude of the regional or local government regarding integration of immigrants and the priority of information transfer among the actors (local community, immigrants, institutions, authorities, entrepreneurs, civil groups, and media) 
profoundly affect the outcomes of the labor market and thus both the social and economic development of the region. Regions of Austria, e.g. Burgenland, capitalize effectively on the migratory flows and their consequences.

\section{Summary}

The study has investigated the linkages between the main types of integration concepts and some factors of national and regional development, such as issues regarding welfare services, social and spatial segregation, comparing the European countries. Integration policies define how easy it is to obtain equal rights in the host country, getting entitlements to welfare benefits. An easy access to these rights may lead immigrants to dependence, not only financially but also regarding their future residence permit or naturalization chances. Besides the social conflicts, this dependence has built barriers against national or local development mainly through the income gap and labor market issues. Naturalization is a common way in Europe to integrate immigrants - with its requirements and entitlements to political, economic, and social advantages. The accessibility of citizenship, but of a residence permit too, varies in Europe.

On the basis of this study, liberal welfare systems and regimes with strict requirements have good labor market integration outcomes and fewer social conflicts. In contrary, countries with multicultural policies and a high level of welfare provisions have difficulties regarding the integration of immigrants in the labor market; labor market participation is lower. Systems with restrictive legal rules and administrative requirements regarding cultural integration, equal rights, and welfare services thus also support social well-being besides economic development. Open countries with easy access to equal rights have poorer outcomes on the labor market and less success in relation to spatial and social segregation.

In summary, the characteristics of a national migration policy have impacts on the economic potential and the well-being of the whole society as well as on the intensity of regional development. Regional and local integration policy have also become ever more important in several countries over the last decades. The cooperative and communicative attitude of regional or local governments and a good information transfer among the actors profoundly affect the outcomes and thus both the social and economic development of the region. 


\section{References}

Balázs, I. (2003). A központi szint alatti közigazgatás helyzete és változásai az EU országokban I-II. [Features and changes of the subnational public administration in the EU Member States I-II]. Magyar Közigazgatás 9-10.

Bandelow, N. C. (2006). Politische Systeme und kollektives Regierungslernen am Beispieldeutscher und britischer Europapolitik [Political systems and collective learning of governing with the example of German and British EU policies]. Zeitschrift für Politikwissenschaft 16(4): 1275-1298.

Banting, K.; Kymlicka, W. (eds). (2006). Multiculturalism and the welfare state: recognition and redistribution in contemporary democracies. Oxford University Press, Oxford.

Barry, B. (2001). Culture and equality: an egalitarian critique of multiculturalism. Harvard Press, Cambridge, MA.

Bauböck, R. (1994). The integration of immigrants. Council of Europe CDMG. Strasbourg.

Biffl, G.; Skrivanek, I.; Steinmayr, A.; Faustmann, A. (2010). Migrantinnen und Migranten auf dem burgenländischen Arbeitsmarkt [Immigrants on the labor market of Burgenland]. AMS Burgenland, Eisenstadt.

Bjerre, L.; Helbling, M.; Römer, F.; Zobel Malisa (2015). Conceptualizing and measuring immigration policies. International Migration Review 3(49): 555600.

Brubaker, R. (1995). National minorities, nationalizing states, and external national homelands in the new Europe. Daedalus 124(2). Accessed from: http://works.bepress.com/wrb/16/, on: 12.5.2016.

City Administration of Vienna (2014). STEP 2025 - Stadtentwicklungsplan Wien [STEP 2025 - Urban development plan of Vienna]. AV + Astoria Verlag, Wien.

De Haas, H.; Natter, K.; Vezzoli, S. (2016). Growing restrictiveness or changing selection? The nature and evolution of migration policies. International Migration Review. Accessed from: http://onlinelibrary.wiley.com/doi/10.1111/ imre.12288/full\#imre12288-note-1001, on: 20.2.2017.

Dustmann, Ch.; Frattini, T. (2012). Immigration: the European experience. Discussion Paper 2012/1. NORFACE Migration.

Ellerman, A. (2013). Migration and citizenship. Newsletter of the American Political Science Association 2013/1.

EUROPEAN COMMISSION (2000). Communication from the Commission to the Council and the European Parliament on a community immigration policy. Executive summary. COM/2000/0757 final. Accessed from: http://eur-lex. europa.eu/legal-content/EN/TXT/?uri=celex\%3 A52000DC0757, on: 10.12.2016. (2003). Communication from the Commission to the Council, the European Parliament, the European Economic and Social Committee, and the Committee of 
the Regions on Immigration, Integration and Employment. Accessed from: http:// europa.eu.int/eur-lex/en/com/cnc/2003/com2003_0336en01.pdf, on: 10.12 . 2016.

(2015). Policies of DG Migration and Home Affairs. Accessed from: http:// ec.europa.eu/dgs/home-affairs/what-we-do/policies/index_en.htm, on: 20.8. 2016.

Fassmann, H.; Münz, R. (1996). Migration in Europa. Historische Entwicklung, aktuelle Trends, politische Reaktionen [Migration in Europe. Historical development, current trends, political reactions]. Campus Verlag, Frankfurt am Main.

Feleky, G. A.; Vincze, A. (2010). A sikeres integráció feltételeinek feltárása [Exploring the factors of the successful integration]. Dél-Alföldi Regionális Társadalomtudományi Egyesület, Szeged.

Florida, R. (2005). Cities and the creative class. Psychology Press, Washington.

Gafner, Ch.; Yale-Loehr, S. (2010). Attracting the best and the brightest. A critique of the current U.S. immigration system. Fordham Urban Law Journal 38(183). Accessed from: https://ssrn.com/abstract=1802690, on: 20.8.2016.

Gächter, E. (2005). Sozialraumanalyse 1990/2000 - Stadt-Region [Analysis of social space 1990/2000 - urban regions]. Verein Region Bern.

Goodhart, D. (2004). Too diverse? Is Britain becoming too diverse to sustain the mutual obligations behind a good society and the welfare system? Prospect 95: 30-37.

Huddleston, T. et al. (2015). Migrant Integration Policy Index (MIPEX). Accessed from: http://www.mipex.eu/play/, on: 12.8.2016.

Jones-Correa, M. (1998). Between two nations. In the political predicament of Latinos in New York City. Cornell University Press.

Koopmans, R. et al. (2005). Contested citizenship. Immigration and cultural diversity in Europe. UMP, Minnesota.

Kováts, A. (2014). Migrációs helyzetkép [Migratory situational picture]. In: Taróssy, I.; Glied, V.;Vörös, Z. (eds.), Migrációs tendenciák napjainkban [Migratory tendencies of today]. Publikon, Pécs, 329-349.

Musterd, S. (2005). Social and ethnic segregation in Europe: levels, causes and effects. Journal of Urban Affairs 27: 331-348.

Myrdal, G. (1960). Beyond the welfare state. Economic planning and its international implications. Duckworth, London.

Niessen, J.; Chopin, I. (2002). Anti-discrimination legalisation in EU Member States. European Monitoring Centre on Racism and Xenophobia. Vienna.

Oltmer, J, (2017). Globale Migration - Geschichte und Gegenwart [Migration history and present]. CH.B. Beck, Munich.

Patay, T. (2016). A migrációs kihívások és megoldások regionális sajátosságai [Regional features of migratory challenges and political solutions]. In: Berghauer, 
S. et al. (eds.), Társadalomföldrajzi kihívások és adekvát válaszlehetöségek a XXI. Század Kelet-Közép-Európájában [Social geographical challenges and search for adequate answers in the East-Central Europe of the $21^{\text {st }}$ century]. Berehove, 380-387.

Patay, T.; Pálmai, É. (2014). A területfejlesztés egy új típusú megközelítése [A new approach to regional development]. In: Takácsné György, K. (ed.), Az átalakuló, alkalmazkodó mezógazdaság és vidék [The changing and adaptable agriculture and countryside]. Károly Róbert Főiskola, Gyöngyös, 1213-1221.

Pennix, R. et al. (2004). Integration of migrants: economic, social, cultural and political dimensions. European Population Forum 2004. UNECE, Geneva.

Rogers, A.; Tillie, J. (2001). Multicultural policies and modes of citizenship in European Cities. Ashgate, Aldershot.

Statistik Austria. (2016). Die Informationsmanager - Statistiken [The information manager - statistics]. Accessed from: http://www.statistik.at/web_de/statistiken/ index.html, on: 5.8.2016.

Todaro, M. P. (1969). A model of labour migration and urban unemployment in less developed countries. American Economic Review 59(1): 137-148. Pittsburgh.

Torma, A. (2003). Önkormányzati reformok Nyugat-Európában és tanulságaik [Reforms of the local government in Western Europe and their lessons]. Accessed from: www.uni-miskolc.hu/ wwwallin/kozig/hirek/eukozig/onk_reform.pdf, on: 16.8.2016.

Treibel, A. (2011). Migration in modernen Gesellschaften - Soziale Folgen von Einwanderung, Gastarbeit und Flucht [Migration in modern societies - social consequences of immigration, guest-work and escape]. Juventa Verlag, Weinheim und München.

Uberoi, V.; T. Modood. (2013). Has multiculturalism in Britain retreated? Soundings 53: 129-142. Dagenham. 